IZA DP No. 6233

Pulls of International Student Mobility

Martin Kahanec

Renáta Králiková

December 2011 


\title{
Pulls of International Student Mobility
}

\author{
Martin Kahanec \\ Central European University, \\ IZA and CELSI \\ Renáta Králiková \\ Central European University \\ and SGI
}

\section{Discussion Paper No. 6233 December 2011}

\author{
IZA \\ P.O. Box 7240 \\ 53072 Bonn \\ Germany \\ Phone: +49-228-3894-0 \\ Fax: +49-228-3894-180 \\ E-mail: iza@iza.org
}

\begin{abstract}
Any opinions expressed here are those of the author(s) and not those of IZA. Research published in this series may include views on policy, but the institute itself takes no institutional policy positions.

The Institute for the Study of Labor (IZA) in Bonn is a local and virtual international research center and a place of communication between science, politics and business. IZA is an independent nonprofit organization supported by Deutsche Post Foundation. The center is associated with the University of Bonn and offers a stimulating research environment through its international network, workshops and conferences, data service, project support, research visits and doctoral program. IZA engages in (i) original and internationally competitive research in all fields of labor economics, (ii) development of policy concepts, and (iii) dissemination of research results and concepts to the interested public.
\end{abstract}

IZA Discussion Papers often represent preliminary work and are circulated to encourage discussion. Citation of such a paper should account for its provisional character. A revised version may be available directly from the author. 
IZA Discussion Paper No. 6233

December 2011

\section{ABSTRACT}

\section{Pulls of International Student Mobility}

Economic theory suggests that high-skilled immigration generally has positive effects on the receiving economy. International student mobility is an important channel through which highskilled immigrants arrive. The purpose of this paper is to identify some of the key determinants of international student mobility among higher education policies. For this purpose we review the existing evidence and compile a longitudinal dataset covering inflows of international students into a number of advanced economies. We then study the effects of various higher education policies on the inflow of international students using parametric as well as non-parametric statistical methods. We conclude that among higher education policies especially the quality of higher education institutions and the availability of programs taught in the English language can act as an important tool to attract international students, and thus high-skilled migrants.

JEL Classification: $\quad 123,128, \mathrm{~J} 21, \mathrm{~J} 24, \mathrm{~J} 61, \mathrm{~J} 68$

Keywords: $\quad$ higher education, education policy, migration, migration policy, student mobility

Corresponding author:

Martin Kahanec

Central European University

Nádor u. 9

1051 Budapest

Hungary

E-mail: kahanecm@ceu.hu 


\section{Introduction}

There seems to be a broad consensus, at least among labor market experts, that highskilled immigration is desirable for Europe (Kahanec and Zimmermann, 2011). Economic theory indeed suggests that high-skilled immigration generally has positive effects on the receiving economy. It may well facilitate the international exchange of ideas, knowledge, goods and services, and capital to a greater extent than low-skilled immigration (Chiswick, 2011, p. 1-3). In view of the complementarities between high-skilled labor and skill-intensive production, success in a global market critically depends on the ability to upgrade the skills of the labor force-also by attracting highskilled workers. Through complementarities between high- and low-skilled labor, the inflow of high-skilled workers increases the demand for their less skilled colleagues, thereby not only helping to alleviate the widespread problem of low-skilled unemployment but also inequality and welfare state sustainability (Kahanec and Zimmermann, 2008, 2009).

International student mobility is an important channel through which high-skilled immigrants arrive (Suter and Jandl, 2006), and it is particularly attractive in view of the high integration potential of high-skilled students (Chiswick and Miller, 2011). The literature points out a number of higher education policies that may affect international student mobility, such as tuition fees, the language of instruction or the quality of the higher education institutions (DeVoretz, 2006).

The purpose of this paper is to evaluate this channel of high-skilled immigration and identify its key determinants among higher education policies. We begin by reviewing the literature on economic effects of high-skilled immigration. Subsequent sections examine the existing evidence on international student mobility as an important channel of high-skilled immigration and discuss higher education policies as a tool to attract international students. Subsequently, using a unique longitudinal dataset and parametric as well as non-parametric econometric methods, we tentatively measure the independent effects of various higher education policies on the degree of internationalization of a country's higher education measured by the share of international students in its student body. We conclude by reviewing the scope for such policies to attract high-skilled immigrants.

\section{The effects of high-skilled migration on host economies}

The impact of immigration on host labor markets depends on the degree of substitutability or complementarity of the migrant and native labor force. This qualitative nature of the interaction between foreign and domestic workers is also fundamental in economic models that conceptualized these relationships (Chiswick, 1980, 1998; Chiswick et al., 1992). To elucidate the effects of immigration, it is of key importance to distinguish high- and low-skilled labor markets in such models. We illustrate these points and establish benchmark theoretical predictions using a simple theoretical setting in Figure 1.

[Figure 1 about here] 
We consider the impact of the immigration of high-skilled workers on an economy with two types of indigenous labor: high- and low-skilled. ${ }^{1}$ For simplicity we assume that high-skilled immigrant labor is perfectly substitutable with high-skilled native labor. Then we can represent such immigration as a shift in the supply curve from $\bar{H}^{0}$ to $\bar{H}^{1}$ (Figure 1a), which moves the equilibrium from $A^{0}$ to $A^{1}$ and the wage down from $w_{h}^{0}$ to $w_{h}^{1}$. The complementarity of high- and low-skilled labor then implies that the increase of high-skilled employment (from $\bar{H}^{0}$ to $\bar{H}^{1}$ ) leads to an outward shift in the demand for low-skilled labor, from $D_{l}^{0}$ to $D_{l}^{1}$ (Figure 1b). Two outcomes may result in the low-skilled market. Under the assumption of a competitive market, wages rise from $w_{l}^{0}$ to $w_{l}^{1}$ at the full employment level $\overrightarrow{L^{0}}$.

If, on the other hand, a wage floor is set for low-skilled workers at $w_{U}$, as is the case for a number of European countries, a lower level of unemployment results $\left(\bar{L}^{0}-L_{U}^{1}\right.$ instead of $\overline{L^{0}}-L_{U}^{0}$ ). As employment goes up from $L_{U}^{0}$ to $L_{U}^{1}$, complementarity between low- and high-skilled labor feeds back into the market for high-skilled labor and results in an upward shift in the demand for high-skilled workers. This to a certain extent offsets the original decline in high-skilled wage, as this increases from $w_{h}^{1}$ to $w_{h}^{2}{ }^{2}$ By a similar argument one can show that low-skilled immigration decreases low-skilled wages (under competitive markets) or increases low-skilled unemployment (under a wage floor), and that it increases high-skilled wage. ${ }^{3}$

This straightforward analysis has a clear message: skilled immigration benefits the low-skilled native labor force and may, but does not need to, hurt high-skilled native workers. Indeed, Kahanec and Zimmermann (2008, 2009) show that high-skilled immigration tends to decrease earnings inequality in the host economy. In addition to these redistributive effects, high-skilled migration may have a number of positive effects. Migrants are often more mobile than natives and thus improve the allocation of production factors and-most notably-human capital in the host economy. Furthermore, immigrants arrive with social capital, which may serve as a vehicle for cross-border exchange of new ideas and knowledge and also facilitate international trade or foreign investment (Bonin et al., 2008). As a result, immigration can expand the production possibilities in the host country and thus increase demand for labor.

There are some arguments why and how immigration might hurt native workers through the fiscal system, with some arguing that immigrants put pressure on the welfare system. However, recent evidence indicates that immigrants in fact face significant barriers when accessing welfare and that their disproportional welfare take-up, if it occurs, is due to their adverse characteristics, which rather result from ill-designed immigration policies in Europe (Giulietti et al., 2011; Zimmermann et al, 2011). Furthermore, imperfect adjustment due to language problems, institutional and

\footnotetext{
${ }^{1}$ Note that whether an immigrant can be considered high- or low-skilled depends not only on how we define high- and low-skilled native labor but also on the transferability of their skills acquired outside the host country and the speed of adjustment to the skill requirements of the host labor market. See also Kahanec and Zimmermann (2009).

${ }^{2}$ The degree of complementarity determines whether the resulting wage is higher or lower than $w_{h}^{0}$. In Figure 1 we show the case where $w_{h}^{2}<w_{h}^{0}$.

${ }^{3}$ See Kahanec, Zaiceva and Zimmermann (2010) for an analysis of low-skilled immigration.
} 
legal barriers, migration trauma or discrimination may lead to substandard labor market outcomes, higher welfare dependency, lower tax contributions and other adverse effects (Borjas, 1999; Brücker et al., 2002).

\section{International student mobility and high-skilled migration}

As shown in the previous section, the composition of immigrant inflows is of key importance for the socio-economic outcomes in a receiving country. One such inflow-international student mobility-is an important channel of high-skilled immigration. In $200527 \%$ of foreign higher education students from a European Union member state were employed in the UK six months after graduating. In Norway $18 \%$ of students from outside the European Economic Area (EEA) studying between 1991 and 2005 stayed in the country, the corresponding number for EEA students was 8\% (Suter and Jandl, 2006). In the US in 1999 a quarter of temporary migrants under the H1-B visa program had been previously enrolled at a US university (Cervantes and Guellec, 2002). Almost half of the immigrants entering Australia through high-skilled immigration provisions had completed their degree there (OECD, 2006, 2011). Clearly, as also pointed out by Ritzen and Marconi (2010), student mobility represents one of the important sources of high-skilled migration.

According to OECD (2011), more than half of the students (53.9\%) studying abroad are found in six countries: the US (18\%), the UK (9.9\%), Australia (7\%), Germany (7\%), France $(6.8 \%)$ and Canada (5.2\%). Other countries which have begun to attract foreign students in greater numbers include: Canada (5.2\%), the Russian Federation $(3.7 \%)$, Japan $(3.6 \%)$ and Spain $(2.3 \%) .{ }^{4}$ These numbers, however, fail to reflect the size of overall student body of a host country that can serve as a proxy for the capacity to absorb international students. A country should not be viewed as being unattractive to international students if it has a smaller absolute number of international students but international students form a large part of its overall student body. For example Switzerland attracts only $1.3 \%$ of overall students studying abroad while international students form almost $15 \%$ of all the students studying in this country. In this paper we therefore use proportion of international students to the whole student body as the measure of inward student mobility. There are five countries where the international students form more than $10 \%$ of the student body: Australia (21.5\%), the UK (15.3\%), Austria (15.1\%), Switzerland (14.9\%) and New Zealand (14.6\%) (OECD, 2011).

\section{Higher education policy as a factor of international student mobility}

A number of competing theories hypothesize various factors conditioning the migration decision as an economically driven phenomenon (Harris and Todaro, 1970; Massey et al., 1994). Although student's migration decisions probably also involve economic incentives, the institutional context of their decision to migrate is different than that of labor migrants. Besides specific provisions for the immigration of foreign

\footnotetext{
${ }^{4}$ These numbers reflect all foreign students and also include those who originally came to the host country for different reasons than studying.
} 
students, higher education policy may be an important factor determining their inflows.

The literature on higher education finds several different factors that influence the inflow of foreign students. Using a cross-section of source countries of students studying in the US, Rosenzweig (2006) proposes that students migrate because the return to their skills at home is relatively low and not in order to acquire skills they cannot acquire in their country of origin. In fact he finds that higher enrolment rates in source countries lead to higher rates of student out-migration. DeVoretz (2006) finds a negative effect of tuition fees for foreign students in Canada. Naidoo (2007) reports similar findings for the UK. Lowel and Khadka (2011) show that although the more stringent visa policies implemented in the US as a consequence of $9 / 11$ somewhat deterred student immigration, the recession of 2001 probably had a greater negative impact. They also confirm the negative role of the cost of education.

OECD (2011) finds the language of instruction an important factor and notes that the most attractive countries use one of the more spoken languages, such as English, French, German, Spanish or Russian. However, English is more and more viewed as lingua franca in higher education and research, and one of the reasons students study abroad is to enhance their proficiency (Altbach, 2007; Zheng, 2010). This importance is underscored by the fact that large share of mobile students (42\%) head to Englishspeaking countries (Australia, Canada, New Zealand, the UK and the US) (OECD, 2011).

The quality of education can also affect inward student mobility and is usually based on two indicators from the position of the students (Bourke, 1997; OECD, 2011). First is the reputation of the higher education institution and second is recognition of the degree in the home country or international labor market (Bourke 1997; Park, 2009). One of the ways reputation is built up is the position of higher education institutions in the international ranking. Degree recognition is formally governed by national legislation. However, in the labor market it is also related to the reputation and standing of the degree-awarding higher education institution.

Other factors which are also important for students include multiculturalism, safety, weather and the friendliness of those who live in the country (Bourke, 1997; Park, 2009). For example, Korean students who value these factors more highly and are less interested in the quality of education tend to choose Australia over the UK or the US (Park, 2009).

\section{Measuring the determinants of student mobility}

Based on the literature reviewed we identify determinants influencing incoming student mobility, which we measure using a purpose-made dataset compiled from three sources: the ARWU, the Migrant Integration Policy Index (MIPEX) and the OECD. ${ }^{5}$ We define incoming mobility of higher education in a given country-our dependent variable - by the percentage of international students to national student body. The independent variables measuring higher education policies are: tuition fees

\footnotetext{
${ }^{5}$ The MIPEX index measures the openness of a country to immigrant integration (MIPEX, 2011).
} 
(and how they compare to domestic students); the share of universities in the ARWU top 100 and $500^{6}$; and the extent English is the language of instruction. Immigration policies are controlled for by country's rank in the MIPEX ranking. We collect this information for 34 countries. Whilst the dependent variable is from the 2005/2006 and 2008/2009 academic year, as it takes time until institutional changes in higher education or migration policies in host countries can affect potential international students, the independent variables with exception of the fees are lagged by one year. ${ }^{7}$

We summarize our data for the 2008/2009 academic year in Table 1 . As these data do not permit simple interpretations we consider simple econometric methods to grasp the relationships between inflows of international students and higher education policies. Acknowledging the obvious limitations of our data such as small sample size, we consider a nonparametric locally weighted scatter-plot smoothing technique (LOWESS) as well as simple ordinary least squares (OLS) and fixed effects (FE) econometric models. ${ }^{8}$

[Table 1 about here]

Some distinct patterns are revealed by the LOWESS plots in Figure 2. In panel (a), even excluding the outlying United States, mobility is increasing - but at a decreasing rate-in the share of higher education institutions in the ARWU top 500. We also see in panel (b) that countries whose programs all have English as the language of instruction attract relatively more international students. It also seems from panel (c) that countries where fees for international students are higher than those applying to domestic students have more international students. It appears in panel (d) that we cannot identify any distinct relationship between higher education mobility and the MIPEX ranking.

[Figure 2 about here]

Using the OLS and fixed effects models, we tentatively evaluate these relationships with regard to their mutual interactions and other confounding factors. ${ }^{9}$ We present OLS models with only linear and quadratic share of universities in the ARWU top 500 (column 1), with variables measuring English instruction and fees as well (3), as well as the respective models without the outlying US, (2) and (4). In all OLS models we control for the year and provide robust standard errors, corrected for country clustering. We then present the corresponding fixed effect models controlling for any time-invariant country-specific factors (5-8).

[Table 2 about here]

\footnotetext{
${ }^{6}$ Note that this variable measures country's share among world's elite higher education institutions, which should not be confused with the overall quality of its higher education.

${ }^{7}$ This accounts for the assumption that students who study abroad in for example academic year 2008/2009 were applying for the studies in 2008 and hence making their decision based on the situation at that time. In the case of fees the situation is different, because universities publish the fees about a year before the academic year starts. It is important to acknowledge here as well that our (lagged) independent variables are relevant mainly for the first year students who form only part of the overall mobile student body.

${ }^{8}$ In the OLS models we pool data for 2006 and 2009, accounting for clustering by countries, whereas in the fixed effects models we treat data as a panel of countries and two years, 2006 and 2009.

${ }^{9}$ We excluded MIPEX index from these regressions due to the small number of observations.
} 
The results from this analysis indicate that the patterns presented in Figure 2 are robust. All models consistently indicate that the share of universities in the ARWU top 500 as a measure of the quality (and reputation) of higher education has a positive effect on the internationalization of higher education and that this effect is humpshaped. ${ }^{10}$ Similarly, it seems that having "no or nearly no" or "all" programs in English is better than having "some" or "many" programs in English.

That having "no or nearly no" programs in English has similar effect as having all programs in English is driven by Austria, which has a very high share of international students in spite of just a few programs in English. Yet Austria is a special caseaccording to OECD (2011) more than half of the international students are from Germany (7450 of 14 260). This might be explained by the close proximity and the fact that students in many of the German federal states have to pay university tuition fees-unlike Austria. Furthermore, a system of numerus clausus operates in some German programs, limiting the number of students who may study.

It would also appear that countries applying no fees and perhaps even more so those charging international students fees higher than those applying to domestic students enjoy higher inflows of international students than countries applying similar fees for international and domestic students. Fees are thus not necessarily negatively correlated with incoming mobility in the raw data, but in fact this stays true also if we control for various potentially confounding factors, including time invariant country fixed effects. Although this needs further scrutiny, we think that rather than contradicting the findings of DeVoretz (2006) or Naidoo (2007), this finding may be due to reverse causality - places at the higher education institutions in these countries are in greater demand and so charge more. In addition, given the limitations of our data, we cannot exclude the possibility that if the quality of education is comparable then the cost of study may determine the choice of country to study (OECD, 2011). ${ }^{11}$ In any case, we view this analysis as tentative and further investigation using larger panel data is necessary.

\section{Policy implications}

Given these results, an important question is whether the student flows are largely exogenous, or whether there are possibilities to actively redirect these flows using higher education policy instruments. Chen and Barnett (2000) argue that the flows of students are relatively stable and there is only limited number of countries which are able to attract international students. They classify countries into three categories: the core where most of the students go, such as Canada, France, Germany, the UK and the US, the semi-periphery such as Eastern Europe, and the periphery that does not attract foreign students, such as Latin American and African countries.

However, there seem to be substantial changes in countries' ability to attract international students, casting doubts on this premise (Ritzen and Marconi, 2011). For

\footnotetext{
${ }^{10}$ Note however, that the estimated coefficients are in several cases insignificant.

${ }^{11}$ Another aspect that we do not account for due to data limitations is that fees for international and domestic students must be the same for students coming from another EU member state. As much as $72 \%$ of foreign students in the $21 \mathrm{EU}$ member states that are also members of the OECD come from one of these 21 member states (OECD, 2011).
} 
example, the US lost $20 \%$ share of world's international students between 1985 and 2009 (from 38\% to 18\%) (Ritzen and Marconi 2011; OECD 2011). Australia and New Zealand, on the other hand, have in Chen and Barnett's (2000) nomenclature turned from peripheries into cores since the 1980s. Australia currently carves out the third largest share of the foreign students in the world and New Zealand increased its share almost five-fold from $0.4 \%$ in 2000 to $1.9 \%$ in 2009 (OECD, 2011). From another perspective, while the number of foreign students enrolled around the world increased by $77 \%$ between 2000 and 2009, in the US it was only $49 \%$ but in Oceania it was $183 \%$ and in Latin America and the Caribbean 161\% (ibid.).

What is the scope of higher education policies to attract international students? A common denominator in student choice is that mobile students prefer Englishspeaking countries. As Altbach (2007) notes English-speaking academic systems dominate and this hegemony is here to stay for the foreseeable future. This, however, does not mean that non-English speaking countries have little chance of attracting international students. The dominant position of English seems to be best addressed by countries introducing large numbers of programs in English, which is the case in Denmark, Finland, the Netherlands and Sweden (OECD, 2011). In Japan, perceived by OECD (2011) as a rising front-runner in student mobility, the introduction of oneyear programs in English increased the number of US students between 1980 and 2000 from 1000 to 40000 (Ninomiya et al., 2009).

Placement in the world rankings, which according to our analysis appears to have strong effects, is probably more difficult to tackle due to inherent inertia of higher education quality. As international students face a degree of informational asymmetry when deciding about where to study (Bourke, 1997), governments and higher education institutions can, besides improving their placement in the world rankings as a long-term aim, concentrate on shorter-term activities mitigating such asymmetry. This may involve marketing of their higher education and concrete institutions, transparent quality control and evaluation systems, information about recognition of the diplomas they offer ${ }^{12}$, and setting up national agencies facilitating and coordinating these efforts. For example in Poland, which has low levels of international students for many years, 40 best universities of the country decided to organize a consortium, which has launched an information campaign (Siwinska, 2009). This campaign helped to increase the number of incoming students by $30 \%$ (ibid.).

In the longer-run the countries that aim to change their position from student exporters to more attractive host country through enhanced quality and possibly enhanced placement in the international rankings need to employ more profound changes. In general they need to enhance the academic environment to attract good quality faculty that is necessary for high quality education (de Wit, 2010). The conditions for good quality faculty should include competitive salaries, research infrastructure, career prospects and abolishing inflexible hierarchies especially for young researchers as it hinders their independent research (Kelo and Wachter, 2004).

\footnotetext{
${ }^{12}$ The governments of the potential host countries should also seek to get its higher education recognized by potential sending countries.
} 


\section{Conclusions}

In this paper we argue that high-skilled immigration is desirable in view of its economic benefits, and that international student mobility is an important vehicle of high-skilled immigration. In view of the benefits of inflows of international students we evaluate the scope for higher education policies to facilitate such inflows.

The literature identifies a number of important factors, such as returns to skills, visa policies and a number of contextual variables such as multiculturalism, safety, weather and the friendliness of people. A number of higher education policies are also identified as important for international student mobility. These include tuition fees and costs of study, language of instruction, and the quality of education and its reputation.

We consider the independent effects of higher education policies using simple nonparametric and parametric models and a unique longitudinal dataset compiled for this purpose.

We find that among these policies it is mainly the quality of higher education as well as the availability of programs with English as the language of instruction that drive inflows of international students. We argue that in the short run policies should increase the number of programs with English as the language of instruction as well as increasing marketing and the transparency of measurement and evaluation of the quality of higher education institutions, whereas the long-run objective needs to be increasing the overall quality of higher education system.

Further research is necessary in order to disentangle various determinants of students' international mobility decision. In particular, a longitudinal and richer dataset would be necessary, as well as a fuller account of the possible endogeneity of higher education policy.

\section{References}

Altbach, P. G. 2007. "The Imperial Tongue: English as the Dominating Academic Language", Economic and Political Weekly, 42(36): 3608 - 3611.

Bonin, H., W. Eichhorst, C. Florman, M. O. Hansen, L. Skiöld, J. Stuhler, K. Tatsiramos, H. Thomasen, K. F. Zimmermann. 2008. "Geographic Mobility in the European Union: Optimising its Economic and Social Benefits", IZA Research Report No. 19, Bonn: Institute for the Study of Labor.

Borjas, G. J. 1999. "Immigration and Welfare Magnets", Journal of Labor Economics, 17(4): $607-637$.

Bourke, A. 1997. "The Internationalisation of Higher Education: The Case of Medical Education”, Higher Education Quarterly, 51(4): 325 - 346.

Brücker, H., G. S. Epstein, B. McCormick, G. Saint-Paul, A. Venturini and K. F. Zimmermann. 2002. "Managing Migration in the European Welfare State", in T. Boeri, G. Hanson and B. McCormick (eds.), Immigration Policy and the Welfare System, Oxford: Oxford University Press, $1-168$.

Cervantes, M. and D. Guellec, 2002 "Fuite des cerveaux: Mythes anciens, réalités nouvelles", L'observateur OCDE $n^{\circ} 230$, Paris: Organisation for Economic Cooperation and Development. 
Chen, T.-M. and Barnett, G. A. 2000. "Research on International Student Flows from a Macro Perspective: A Network Analysis of 1985, 1989 and 1995", Higher Education, 39(4): 435 - 453.

Chiswick, B. R. 1980. An Analysis of the Economic Progress and Impact of Immigrants, Employment and Training Administration, Prepared for the US Department of Labor, Washington DC: National Technical Information Service.

Chiswick, B. R. 1998. "The Economic Consequences of Immigration: Application to the United States and Japan”, in M. Weiner and T. Hanami (eds.), Temporary Workers or Future Citizens? Japanese and US Migration Policies, New York: New York University Press, 177 - 208.

Chiswick, B. R. (ed.) 2011. High-Skilled Immigration in a Globalized Labor Market, Washington DC: American Enterprise Institute.

Chiswick, B. R. and P. W. Miller. 2011. "Educational Mismatch: Are High-Skilled Immigrants Really Working in High-Skilled Jobs, and What Price Do They Pay If They Are Not?", in B. R. Chiswick, High-Skilled Immigration in a Globalized Labor Market, Washington DC: American Enterprise Institute, 111 - 154.

Chiswick, C. U., B. R. Chiswick and G. Karras. 1992. "The Impact of Immigrants on the Macroeconomy", Carnegie-Rochester Conference Series on Public Policy, 37(1): $279-316$.

DeVoretz, D. J. 2006. The Education, Immigration and Emigration of Canada's Highly Skilled Workers in the $21^{\text {st }}$ Century, Washington DC: Georgetown's Institute for the Study of International Migration.

de Wit, H. 2010. "Recent Trends and Issues in International Students Mobility" International Higher Education, 59: 13 - 14.

Giulietti, C., M. Guzi, M. Kahanec, K. F. Zimmermann. 2011. "Unemployment Benefits and Immigration: Evidence from the EU", IZA Discussion Paper No. 6075, Bonn: Institute for the Study of Labor.

Harris, J. R. and M. P. Todaro. 1970. "Migration, Unemployment and Development: A Two-Sector Analysis", The American Economic Review, 60(1): 126 - 142.

Kahanec, M., A. Zaiceva and K. F. Zimmermann. 2010. "Lessons from Migration after EU Enlargement," in M. Kahanec and K. F. Zimmermann (eds.), EU Labor Markets after Post-Enlargement Migration, Springer: Berlin, 3 - 45.

Kahanec, M. and K. F. Zimmermann. 2008. "Migration, the Quality of the Labour Force and Economic Inequality", IZA Discussion Paper No. 3560, Bonn: Institute for the Study of Labor.

Kahanec, M. and K. F. Zimmermann. 2009. "International Migration, Ethnicity, and Economic Inequality", in W. Salverda, B. Nolan and T. M. Smeeding (eds.), The Oxford Handbook of Economic Inequality, Oxford: Oxford University Press, $455-490$.

Kahanec, M. and K. F. Zimmermann. 2011. "High-Skilled Immigration Policy in Europe", in B. R. Chiswick, High-Skilled Immigration in a Globalized Labor Market, Washington DC: American Enterprise Institute, 264 - 314.

Kelo, M. and B. Wachter, B. 2004. Brain Drain and Brain Gain: Migration in the European Union after Enlargement, The Hague: Nuffic.

Lowell, B. L. and P. Khadka. 2011. "Trends in Foreign-Student Admissions to the United States: Policy and Competitive Effects" in B. R. Chiswick, High-Skilled Immigration in a Globalized Labor Market, Washington DC: American Enterprise Institute, 83 - 108. 
Massey, D. S., J. Arango, G. Hugo, A. Kouaouci, A. Pellegrino and J. E. Taylor. 1994. "An Evaluation of International Migration Theory: The North American Case", Population and Development Review, 20(4): 699 - 751.

MIPEX. 2011. Migrant Integration Policy Index III, Brussels: British Council and Migration Policy Group.

Naidoo, V. 2007. "Research on the Flow of International Students to UK Universities: Determinants and Implications", Journal of Research in International Education, 6(3): 287 - 307.

Ninomyia, A., J. Knight and A. Watanabe 2009, "The Past, Present, and Future of Internationalization in Japan", Journal of Studies in International Education 13(2): $117-124$.

OECD. 2006. International Migration Outlook 2006, Paris: Organisation for Economic Co-operation and Development.

OECD. 2011. Education at a Glance 2011: OECD Indicators, Paris: Organisation for Economic Co-operation and Development.

Park, E. L. 2009. "Analysis of Korean Students' International Mobility by 2-D Model: Driving Force Factor and Directional Factor", Higher Education 57(6): $741-755$.

Ritzen, J. M. M. and G. Marconi. 2011. "Internationalization in European Higher Education”, International Journal of Innovation Science, 3(2): 83 - 100.

Rosenzweig, M. R. 2006. "Global Wage Differences and International Student Flows", Brookings Trade Forum, 57 - 86.

Siwinska, B. 2009. "Poland: Problems of Internationalization", International Higher Education 55: $11-12$.

Suter B. and M. Jandl. 2006. Comparative Study on Policies towards Foreign Graduates: Study on Admission and Retention Policies towards Foreign Students in Industrialised Countries, Vienna: International Centre for Migration Policy Development

Zheng, J. 2010, "Neoliberal Globalization, Higher Education Policies and International Student Flows: An Exploratory Case Study of Chinese Graduate Student Flows to Canada", Journal of Alternative Perspectives in the Social Sciences, 2(1): 216 - 244.

Zimmermann, K. F., M. Kahanec, A. Barrett A. et al. 2011. Study on Active Inclusion of Immigrants, IZA Research Report, forthcoming. 
Figures and Tables

Figure 1. The effect of high-skilled immigration on high- and low- skilled labor

(a) High-skilled

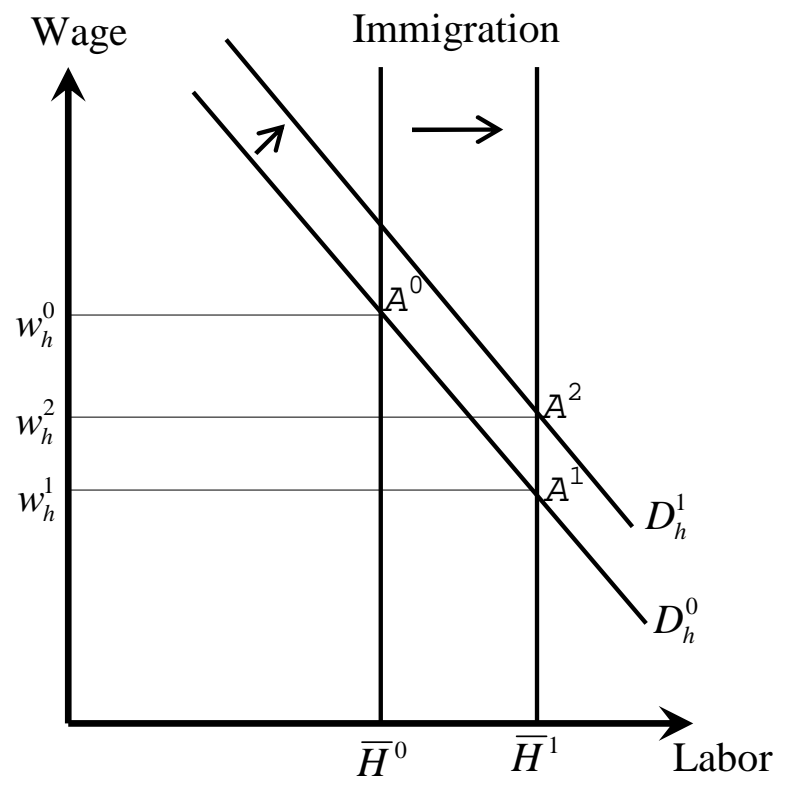

(b) Low-skilled

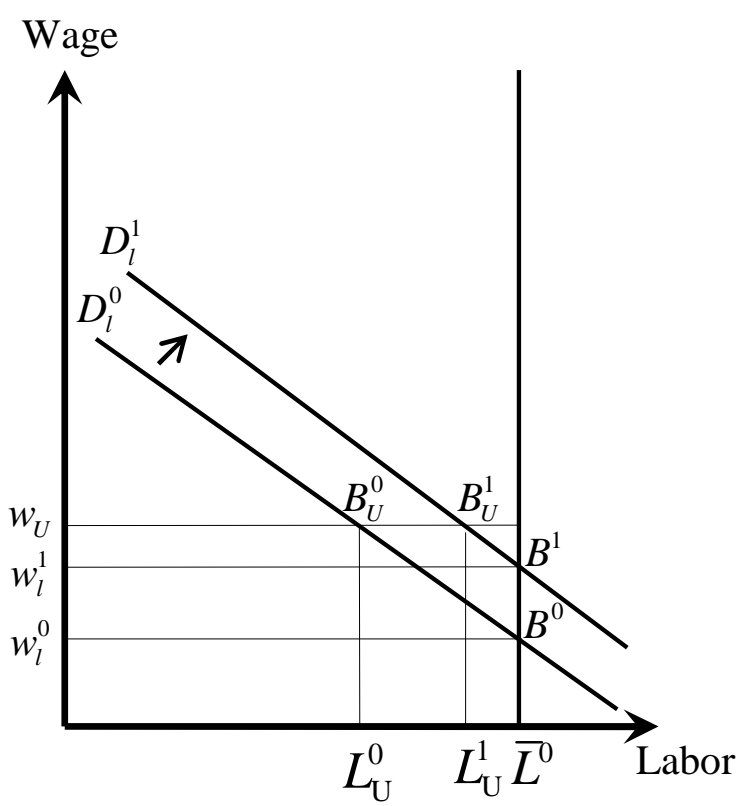


Figure 2. International student mobility

(a)

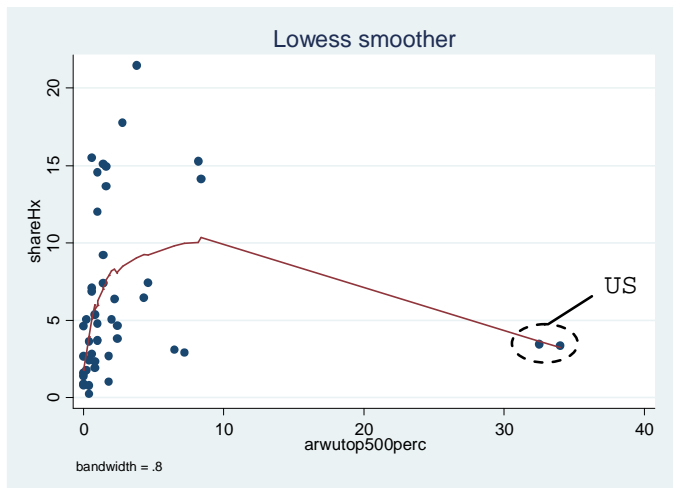

(c)

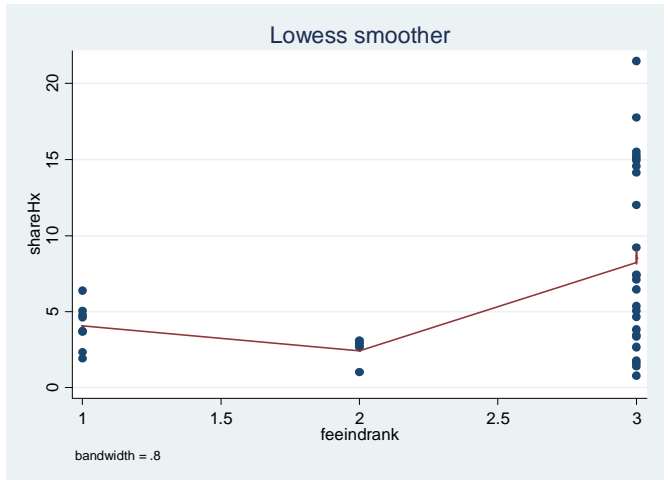

(b)

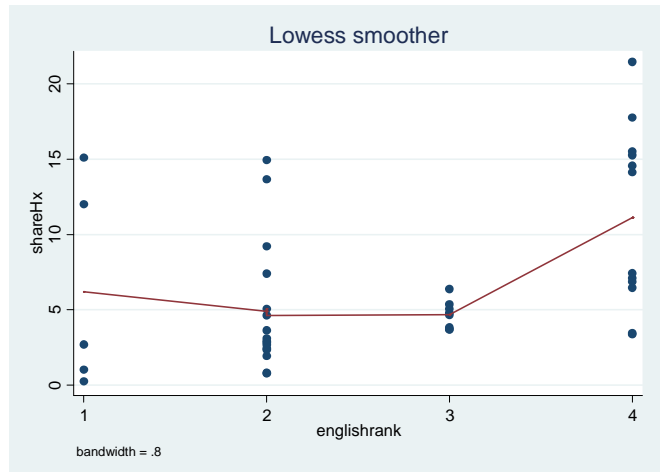

(d)

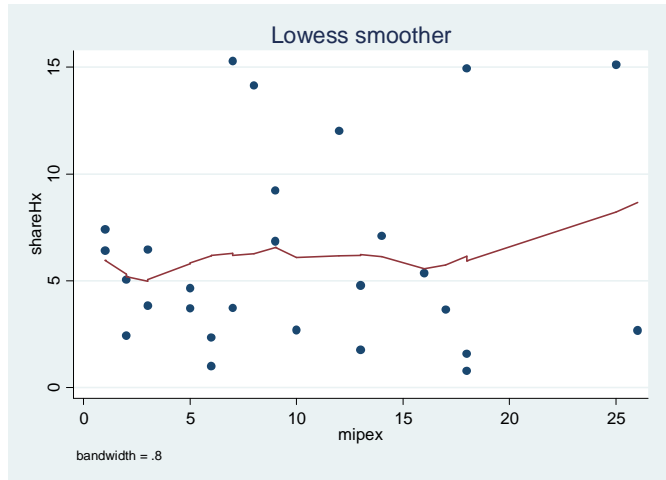

Notes: Locally weighted scatter-plot smoothed (LOWESS) plots. (a-d) shareHx share of international students to national student body in \%; (a) arwutop500perc - the share of higher education institutions in the ARWU top 500; (b) englishrank - English as language of instruction: all or nearly all (4), many programs (3), some programs (2), no or nearly no programs (1); (c) feeindrank - higher (3) or same (2) fees for international as for domestic students, no fees for any students (1); mipex - MIPEX index, rank out of 28 assessed countries in 2007. 
Table 1: The inward student mobility and its determinants

\begin{tabular}{|c|c|c|c|c|c|c|c|c|c|c|c|c|c|}
\hline \multirow[t]{2}{*}{$\begin{array}{l}\text { OECD } \\
\text { countries }\end{array}$} & \multicolumn{3}{|c|}{$\begin{array}{c}\text { Number of students in the academic } \\
\text { year } 2008 / 2009^{1}\end{array}$} & \multicolumn{4}{|c|}{$\begin{array}{l}\text { Fees in the academic year } 2008 / 2009 \text { in equivalent USD } \\
\text { converted using purchasing power parity (PPP) }{ }^{1}\end{array}$} & \multicolumn{4}{|c|}{$\begin{array}{c}\text { Country's performance in the ARWU world } \\
\text { ranking in } 2007^{2}\end{array}$} & \multirow[t]{2}{*}{$\begin{array}{l}\text { English as } \\
\text { the } \\
\text { language of } \\
\text { instruction }\end{array}$} & \multirow[t]{2}{*}{$\begin{array}{l}\text { MIPEX } \\
\text { rank in } \\
2007^{3} \\
\end{array}$} \\
\hline & $\begin{array}{c}\text { Internatio } \\
\text { nal } \\
\text { students to } \\
\text { national } \\
\text { student } \\
\text { body in \% }\end{array}$ & $\begin{array}{c}\text { Foreign } \\
\text { students to } \\
\text { all foreign } \\
\text { students in } \\
\text { the world } \\
\text { in \% }\end{array}$ & $\begin{array}{c}\text { Foreign } \\
\text { students } \\
\text { to national } \\
\text { student } \\
\text { body in \% }\end{array}$ & $\begin{array}{c}\text { Fees for } \\
\text { domestic } \\
\text { students at } \\
\text { public } \\
\text { institutions }\end{array}$ & $\begin{array}{c}\text { Fees for } \\
\text { international } \\
\text { students at } \\
\text { public } \\
\text { institutions } \\
\text { (relative to } \\
\text { domestic) } \\
\end{array}$ & $\begin{array}{c}\text { Government } \\
\text { dependent } \\
\text { private } \\
\text { institutions }\end{array}$ & $\begin{array}{c}\text { Independent } \\
\text { private } \\
\text { institutions }\end{array}$ & $\begin{array}{c}\text { Rank } \\
\text { (top 100) }\end{array}$ & $\begin{array}{l}\% \text { of the } \\
\text { top } 100 \\
\text { universities } \\
\text { originating } \\
\text { from this } \\
\text { country }\end{array}$ & $\begin{array}{c}\text { Rank } \\
\text { (top 500) }\end{array}$ & $\begin{array}{l}\% \text { of the } \\
\text { top 500 } \\
\text { universities } \\
\text { originating } \\
\text { from this } \\
\text { country }\end{array}$ & & \\
\hline Australia & 21.5 & 7 & 24.4 & 4140 & Higher & NA & 8933 & 9 & 2 & 8 & 3.8 & All & No data \\
\hline UK & 15.3 & 9.9 & 20.7 & NA & Higher & 4840 & No data & 2 & 10.9 & 2 & 8.2 & All & 7 \\
\hline Austria & 15.1 & 1.6 & 19.4 & 853 & Higher & 853 & 235 to 11735 & $\begin{array}{c}\text { No } \\
\text { placement }\end{array}$ & 0 & 15 & 1.4 & No & 25 \\
\hline Switzerland & 14.9 & 1.3 & 21.2 & 879 & Higher & No data & 7262 & 8 & 3 & 13 & 1.6 & Some & 18 \\
\hline New Zealand & 14.6 & 1.9 & 26.5 & 3019 & Higher & 4159 & No data & $\begin{array}{c}\text { No } \\
\text { placement }\end{array}$ & 0 & 19 & 1 & All & No data \\
\hline Belgium & 9.2 & 1.3 & 12.6 & $\begin{array}{c}\text { Flanders: } \\
\text { No data; } \\
\text { Wallonia: } \\
599\end{array}$ & Higher & $\begin{array}{c}\text { Flanders: } 545 \text { to } \\
\text { 618; Wallonia: } \\
683\end{array}$ & No data & $\begin{array}{c}\text { No } \\
\text { placement }\end{array}$ & 0 & 15 & 1.4 & $\begin{array}{c}\text { Flanders: } \\
\text { Some. } \\
\text { Wallonia: } \\
\text { No }\end{array}$ & 9 \\
\hline Ireland & 7.1 & & 7.1 & $\begin{array}{c}\text { from } 2800 \\
\text { to } 10000\end{array}$ & Higher & NA & No data & $\begin{array}{c}\text { No } \\
\text { placement }\end{array}$ & 0 & 26 & 0.6 & All & 14 \\
\hline Canada & 6.5 & 5.2 & 13.2 & 3774 & Higher & No data & No data & 5 & 4 & 6 & 4.3 & All & 3 \\
\hline Sweden & 6.4 & 1.1 & 9.4 & $\begin{array}{l}\text { No tuition } \\
\text { fees }\end{array}$ & No fees & No tuition fees & No data & 5 & 4 & 11 & 2.2 & Many & 1 \\
\hline Denmark & 5.4 & No data & 9.6 & $\begin{array}{l}\text { No tuition } \\
\text { fees }\end{array}$ & Higher & No data & NA & 11 & 1 & 23 & 0.8 & Many & 16 \\
\hline Iceland & 4.6 & No data & 5.5 & $\begin{array}{l}\text { No tuition } \\
\text { fees }\end{array}$ & No fees & 2311 to 6831 & $\begin{array}{c}8433 \text { to } \\
12650\end{array}$ & $\begin{array}{c}\text { No } \\
\text { placement }\end{array}$ & 0 & $\begin{array}{c}\text { No } \\
\text { placement }\end{array}$ & 0 & Some & No data \\
\hline Netherlands & 3.8 & 1.2 & 7.2 & 1851 & Higher & NA & No data & 9 & 2 & 10 & 2.4 & Many & 3 \\
\hline Finland & 3.7 & No data & 4.2 & $\begin{array}{l}\text { No tuition } \\
\text { fees }\end{array}$ & No fees & No tuition fees & NA & 11 & 1 & 19 & 1 & Many & 5 \\
\hline Hungary & 3.7 & No data & 4.3 & No data & No data & No data & No data & $\begin{array}{c}\text { No } \\
\text { placement }\end{array}$ & 0 & 27 & 0.4 & Some & 17 \\
\hline United States & 3.5 & 18 & No data & 6312 & Higher & NA & 22852 & 1 & 53.5 & 1 & 32.5 & All & No data \\
\hline Japan & 3.1 & 3.6 & 3.4 & 4602 & Same & NA & 7247 & 3 & 5.9 & 4 & 6.5 & Some & No data \\
\hline Spain & 2.7 & 2.3 & 4.7 & 1038 & Same & NA & No data & $\begin{array}{c}\text { No } \\
\text { placement }\end{array}$ & 0 & 12 & 1.8 & No & 10 \\
\hline
\end{tabular}




\begin{tabular}{|c|c|c|c|c|c|c|c|c|c|c|c|c|c|}
\hline $\begin{array}{l}\text { Slovak } \\
\text { Republic }\end{array}$ & 2.7 & No data & 2.8 & $\begin{array}{l}\text { Maximum } \\
2707\end{array}$ & Higher & NA & No data & $\begin{array}{c}\text { No } \\
\text { placement }\end{array}$ & 0 & $\begin{array}{c}\text { No } \\
\text { placement }\end{array}$ & 0 & Some & 26 \\
\hline Portugal & 2.4 & No data & 4.8 & 1233 & No data & 4991 & No data & $\begin{array}{c}\text { No } \\
\text { placement }\end{array}$ & 0 & 27 & 0.4 & Some & 2 \\
\hline Norway & 2.3 & No data & 8.0 & $\begin{array}{l}\text { No tuition } \\
\text { fees }\end{array}$ & No fees & Data value nil & 5641 & 11 & 1 & 23 & 0.8 & Some & 6 \\
\hline Slovenia & 1.8 & No data & 1.7 & No data & Higher & No data & No data & $\begin{array}{c}\text { No } \\
\text { placement }\end{array}$ & 0 & 35 & 0.2 & No data & 13 \\
\hline Estonia & 1.6 & No data & 3.7 & NA & Higher & No data & No data & $\begin{array}{c}\text { No } \\
\text { placement }\end{array}$ & 0 & $\begin{array}{c}\text { No } \\
\text { placement }\end{array}$ & 0 & No data & 18 \\
\hline Poland & 0.8 & No data & 0.8 & $\begin{array}{c}\text { data value } \\
\text { nil }\end{array}$ & Higher & NA & $\begin{array}{c}\text { from } 1889 \text { to } \\
2537\end{array}$ & $\begin{array}{c}\text { No } \\
\text { placement }\end{array}$ & 0 & 27 & 0.4 & Some & 18 \\
\hline Chile & 0.3 & No data & 0.9 & No data & No data & No data & No data & $\begin{array}{c}\text { No } \\
\text { placement }\end{array}$ & 0 & 27 & 0.4 & No & No data \\
\hline $\begin{array}{l}\text { Czech } \\
\text { Republic }\end{array}$ & No data & No data & 7.3 & $\begin{array}{l}\text { No tuition } \\
\text { fees }\end{array}$ & Higher & NA & No data & $\begin{array}{c}\text { No } \\
\text { placement }\end{array}$ & 0 & 35 & 0.2 & Some & 22 \\
\hline France & No data & 6.8 & 11.5 & 190 to 1309 & Same & 1127 to 8339 & 1128 to 8339 & 5 & 4 & 5 & 4.5 & Some & 12 \\
\hline Germany & No data & 7 & 10.5 & No data & Same & No data & No data & 3 & 5.9 & 3 & 8 & Some & 11 \\
\hline Greece & No data & No data & No data & No data & No data & No data & No data & $\begin{array}{c}\text { No } \\
\text { placement }\end{array}$ & 0 & 27 & 0.4 & No & 23 \\
\hline Israel & \begin{tabular}{|l|} 
No data \\
\end{tabular} & No data & No data & NA & No data & No data & No data & 11 & 1 & 15 & 1.4 & No & No data \\
\hline Italy & No data & 1.8 & 3.3 & 1281 & Same & NA & 4713 & $\begin{array}{c}\text { No } \\
\text { placement }\end{array}$ & 0 & 7 & 3.9 & No & 8 \\
\hline Korea & No data & 1.4 & 1.6 & 5315 & Same & NA & 9586 & $\begin{array}{c}\text { No } \\
\text { placement }\end{array}$ & 0 & 13 & 1.6 & Some & No data \\
\hline Luxembourg & No data & No data & No data & No data & No data & No data & No data & $\begin{array}{c}\text { No } \\
\text { placement }\end{array}$ & 0 & $\begin{array}{c}\text { No } \\
\text { placement }\end{array}$ & 0 & No & 14 \\
\hline Mexico & No data & No data & No data & $\begin{array}{l}\text { No tuition } \\
\text { fees }\end{array}$ & Same & NA & 5365 & $\begin{array}{c}\text { No } \\
\text { placement }\end{array}$ & 0 & 35 & 0.2 & No & No data \\
\hline Turkey & No data & No data & 0.7 & No data & Higher & NA & No data & $\begin{array}{c}\text { No } \\
\text { placement }\end{array}$ & 0 & 35 & 0.2 & Some & No data \\
\hline
\end{tabular}

Sources: ${ }^{1}$ OECD (2011); ${ }^{2}$ www.arwu.org/ARWUAnalysis2007.jsp; ${ }^{3}$ www.mipex.eu/countries.

Notes: International students are based on the OECD (2011) methodology students who go abroad for study purpose. Foreign students are based on the OECD (2011) methodology "All students with different citizenship than the one of the host country". These students could originally come to the host country for different reason than studying. The use of English as language of instruction is expressed in the following categories in the table: All or nearly all (All), Many programs (Many), Some programs (Some), no or nearly no programs (No). 
Table 2. Determinants of international student mobility

\begin{tabular}{|c|c|c|c|c|c|c|c|c|}
\hline & \multicolumn{4}{|c|}{ OLS } & \multicolumn{4}{|c|}{ Fixed effects } \\
\hline & $(1)$ & $(2)$ & (3) & $(4)$ & $(5)$ & $(6)$ & (7) & $(8)$ \\
\hline Share in ARWU top 500 & $\begin{array}{l}1.254^{*} \\
(0.694)\end{array}$ & $\begin{array}{c}2.845 \\
(1.806)\end{array}$ & $\begin{array}{c}0.832 \\
(0.530)\end{array}$ & $\begin{array}{c}1.661 \\
(2.541)\end{array}$ & $\begin{array}{l}1.091 \text { *** } \\
(0.471)\end{array}$ & $\begin{array}{c}2.336^{* *} \\
(1.156)\end{array}$ & $\begin{array}{l}1.011^{*} \\
(0.609)\end{array}$ & $\begin{array}{l}2.834^{*} \\
(1.509)\end{array}$ \\
\hline Share in ARWU top 500, squared & $\begin{array}{c}-0.0388^{*} \\
(0.020)\end{array}$ & $\begin{array}{l}-0.254 \\
(0.234)\end{array}$ & $\begin{array}{c}-0.0317 * * * \\
(0.015)\end{array}$ & $\begin{array}{c}-0.131 \\
(0.281)\end{array}$ & $\begin{array}{c}-0.0299 * * \\
(0.014)\end{array}$ & $\begin{array}{l}-0.139 \\
(0.144)\end{array}$ & $\begin{array}{c}-0.0331^{* *} * \\
(0.017)\end{array}$ & $\begin{array}{l}-0.200 \\
(0.176)\end{array}$ \\
\hline No programs in English & & & $\begin{array}{c}6.277 * * \\
(2.343)\end{array}$ & $\begin{array}{c}6.601 * * \\
(2.725)\end{array}$ & & & $\begin{array}{c}7.373 \\
(4.860)\end{array}$ & $\begin{array}{l}8.659^{*} \\
(4.529)\end{array}$ \\
\hline Some programs in English & & & $\begin{array}{c}1.204 \\
(1.670)\end{array}$ & $\begin{array}{c}1.746 \\
(2.465)\end{array}$ & & & $\begin{array}{c}1.687 \\
(3.093)\end{array}$ & $\begin{array}{c}2.893 \\
(2.999)\end{array}$ \\
\hline All programs in English & & & $\begin{array}{l}6.209^{*} \\
(3.265)\end{array}$ & $\begin{array}{c}6.430 \\
(3.773)\end{array}$ & & & $\begin{array}{l}5.791 \\
(3.526)\end{array}$ & $\begin{array}{l}5.657 * \\
(3.278)\end{array}$ \\
\hline No fees & & & $\begin{array}{l}6.866^{* *} \\
(2.925)\end{array}$ & $\begin{array}{l}7.426^{*} \\
(3.701)\end{array}$ & & & $\begin{array}{l}8.660^{*} \\
(4.719)\end{array}$ & $\begin{array}{l}11.12 * * \\
(4.500)\end{array}$ \\
\hline Higher fees & & & $\begin{array}{c}8.732 * * * \\
(2.574)\end{array}$ & $\begin{array}{c}9.091 * * * \\
(3.015)\end{array}$ & & & $\begin{array}{l}9.065^{*} \\
(4.659)\end{array}$ & $\begin{array}{c}11.70 * * * \\
(4.456)\end{array}$ \\
\hline Year 2006 & $\begin{array}{c}-0.080 \\
(0.421)\end{array}$ & $\begin{array}{l}-0.149 \\
(0.420)\end{array}$ & $\begin{array}{c}-0.209 \\
(0.639)\end{array}$ & $\begin{array}{l}-0.328 \\
(0.640)\end{array}$ & $\begin{array}{c}-0.705^{* * *} \\
0.26\end{array}$ & $\begin{array}{c}-0.728 * * * \\
0.269\end{array}$ & $\begin{array}{c}-0.585 \\
0.388\end{array}$ & $\begin{array}{c}-0.579 \\
0.41\end{array}$ \\
\hline Constant & $\begin{array}{c}4.578 * * * \\
(1.247) \\
\end{array}$ & $\begin{array}{c}3.443^{* *} \\
(1.325) \\
\end{array}$ & $\begin{array}{r}-4.009 \\
(3.324) \\
\end{array}$ & $\begin{array}{l}-5.460 \\
(6.091) \\
\end{array}$ & $\begin{array}{c}4.651^{* * * *} \\
(1.315) \\
\end{array}$ & $\begin{array}{c}3.558^{* *} \\
(1.471) \\
\end{array}$ & $\begin{array}{r}-5.349 \\
(5.694) \\
\end{array}$ & $\begin{array}{l}-10.29 * \\
(5.848) \\
\end{array}$ \\
\hline Observations & 45 & 43 & 34 & 32 & 45 & 43 & 34 & 32 \\
\hline R-squared & 0.161 & 0.191 & 0.613 & 0.609 & 0.125 & 0.17 & 0.583 & 0.574 \\
\hline
\end{tabular}

Notes: Robust standard errors in parentheses; *** $\mathrm{p}<0.01,{ }^{* *} \mathrm{p}<0.05,{ }^{*} \mathrm{p}<0.1$

Reference: "Many programs in English"; "Same fees"; Year 2009. 